\title{
Increasing the availability of threonine, isoleucine, valine, and leucine relative to lysine while maintaining an ideal ratio of lysine:methionine alters mammary cellular metabolites, mammalian target of rapamycin signaling, and gene transcription
}

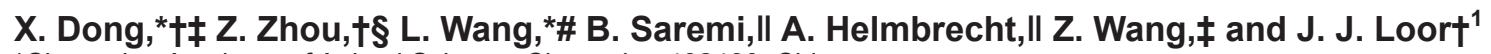 \\ ${ }^{*}$ Chongqing Academy of Animal Science, Chongqing 402460, China \\ †Mammalian NutriPhysioGenomics, Department of Animal Sciences and Division of Nutritional Sciences, University of Illinois, Urbana 61801 \\ ¥Key Laboratory for Animal Disease-Resistance Nutrition of China Ministry of Education, Animal Nutrition Institute \\ of Sichuan Agricultural University, Ya'an, 625014, Sichuan Province, China \\ $\S$ Department of Animal and Veterinary Sciences, Clemson University, Clemson, SC 29634 \\ \#Southwest University, Rongchang, Chongqing 402460, China \\ IIEvonik Nutrition and Care GmbH, 63457 Hanau-Wolfgang, Germany
}

\begin{abstract}
Amino acids not only serve as precursors for protein synthesis but also function as signaling molecules that can regulate the mammalian target of rapamycin (mTOR) pathway. Methionine and Lys are the mostlimiting AA for milk production and a ratio of $\sim 3: 1$ Lys: Met in the metabolizable protein has been determined to be ideal. Besides Met and Lys, recent studies have evaluated Ile, Leu, Val, and Thr as potentially limiting for milk protein synthesis. The objective of this experiment was to determine if varying the ratio of Lys:Thr, Lys:Ile, Lys:Val, and Lys:Leu while maintaining an ideal ratio of Lys:Met and fixed ratio of other essential AA (IPAA) elicits changes in intracellular metabolites, gene transcription related to protein synthesis, and phosphorylation status of mTOR pathway proteins. Immortalized bovine mammary epithelial cell line (MAC$\mathrm{T})$ cells were incubated for $12 \mathrm{~h}(\mathrm{n}=5$ replicates/treatment) with IPAA (2.9:1 Lys:Met; 1.8:1 Lys:Thr; 2.38:1 Lys:His; 1.23:1 Lys:Val; 1.45:1 Lys:Ile; 0.85:1 Lys:Leu; 2.08:1 Lys:Arg) or IPAA supplemented with Thr, Ile, Val, and Leu to achieve a Lys:Thr 1.3:1 (LT1.3), Lys: Ile 1.29:1 (LI1.29), Lys:Val 1.12:1 (LV1.12), or Lys:Leu 0.78:1 (LL0.78). Compared with IPAA, metabolomics via gas chromatography-mass spectrometry revealed that increases in availability of Thr, Ile, Val, and Leu led to greater concentrations of essential AA (Leu, Ile, Thr), nonessential AA (Gly, Glu, Gln, Ser, Pro, Asp), and various metabolites including uric acid, phosphoric acid, $N$-acetylglutamic acid, and intermediates of glycolysis and the tricarboxylic acid cycle. Compared with other treatments, LV1.12 led to greater phosphorylation
\end{abstract}

Received August 18, 2017.

Accepted February 5, 2018

${ }^{1}$ Corresponding author: jloor@illinois.edu status of serine/threonine kinase B (Akt), mTORC1, and ribosomal protein $\mathrm{S} 6$ and lower phosphorylation of $\alpha$ subunit of eukaryotic translation initiation factor 2. In addition, LV1.12 upregulated abundance of CSN2 and both the abundance and promoter methylation of CSN1S1. Although LI1.29 led to the second highest response in mTORC1 phosphorylation status, it resulted in the lowest phosphorylation of Akt and eEF2 and mRNA abundance of CSN2 and various AA transporters (SLC7A5, SLC36A1, SLC38A2, SLC38A9, $S L C 43 A 1)$. Overall, data indicate that an increase in Val at an ideal ratio of Lys:Met could further enhance milk protein synthesis by altering intracellular concentrations of essential AA and metabolites that could play a regulatory role, increasing phosphorylation status of mTORC1 and key signaling proteins, and upregulation of AA transporters.

Key words: essential amino acid ratio, metabolomics, milk protein synthesis, lactation

\section{INTRODUCTION}

It has been estimated that only up to $38 \%$ of the total AA flux across the mammary gland is used for milk protein synthesis; hence, additional capture of dietary $\mathrm{N}$ is a challenge of economic and environmental importance facing the modern dairy industry (Huhtanen and Hristov, 2009; Toerien et al., 2010; Wang et al., 2010). Recent studies demonstrated that balancing EAA profiles could improve milk protein synthesis (Haque et al., 2015). Methionine and Lys are the most-limiting AA for milk protein synthesis, and a ratio of $\sim 3: 1$ of Lys to Met was determined to be ideal in the context of in vitro casein protein synthesis through alterations in mTOR pathway phosphorylation status and mRNA abundance (Nan et al., 2014). In addition to Lys and Met, recent studies revealed that Ile, Leu, Val, and Thr 
could be limiting for optimal protein synthesis (Appuhamy et al., 2011b, 2012; Doelman et al., 2015; Zhou et al., 2015).

It is now well known that AA not only serve as precursors for milk protein but also function as signaling molecules to regulate the mammalian target of rapamycin (mTOR) pathway and, in turn, protein synthesis (Yang et al., 2006; Xie and Proud, 2014). Upon activation by AA, mammalian target of rapamycin complex 1 (mTORC1) phosphorylates eukaryotic initiation factor $4 \mathrm{E}$ binding protein 1 (4EBP1) and ribosomal protein S6 kinase (S6K1; Appuhamy et al., 2011a) followed by ribosomal protein S6 (RPS6), a subunit of eukaryotic translation initiation factor $2(\mathbf{e I F} \mathbf{\alpha})$, and eukaryotic translation elongation factor 2 (eEF2) with the end result being the stimulation of mRNA translation initiation and elongation (Doerks et al., 2002; Browne and Proud, 2004; Kimball and Jefferson, 2006; Shimobayashi and Hall, 2014).

The serine/threonine kinase Akt plays an important role in the regulation of mTORC1 activity and forms part of the phosphatidylinositol 3-phosphate kinase (PI3K)-Akt-mTOR pathway (Inoki et al., 2002; Xie and Proud, 2014). The most consistent response of mTORC1 to AA is an increase in activity with Leu (Jewell et al., 2013). It is still unclear, however, whether bovine mammary cells respond to increases in the availability of other EAA when the Lys:Met ratio is maintained at the ideal level.

In this study, the general hypothesis was that increasing the in vitro availability of Ile, Leu, Val, and Thr while maintaining an ideal ratio of Lys:Met in mammary cells could influence the phosphorylation status of the mTOR signaling pathway along with gene transcription and intracellular metabolites. Thus, to address this hypothesis we cultured the immortalized bovine mammary epithelial cell line (MAC-T), a nonlactating mammary cell line, with various ratios of Lys:Thr, Lys:Ile, Lys:Val, or Lys:Leu and used metabolomics via GC-MS, Western blot, gene transcription, and casein promoter methylation analyses to determine holistic biological responses (Loor et al., 2013).

\section{MATERIALS AND METHODS}

\section{Cell Culture}

The cell culture was performed using the immortalized MAC-T cell line. The MAC-T cells were incubated in culture dishes $\left(1.8 \times 10^{6}\right.$ cells, $\left.100 \mathrm{~mm}\right)$ to generate enough biological material for metabolomics, and on 6 -well plates $\left(0.2 \times 10^{6}\right.$ cells/well $)$ to isolate RNA and protein for Western blot. In both instances, cells were incubated at $37^{\circ} \mathrm{C}$ in an atmosphere of $5 \% \mathrm{CO}_{2}$ and air, and grown to approximately $90 \%$ confluence before imposing treatments exactly as described by Kadegowda et al. (2009).

\section{Treatments and Experimental Design}

Details of treatments and experimental design are included in Supplemental Materials and Table S1 (https://doi.org/10.3168/jds.2017-13707). Three independent batches of cell culture were performed to generate material for metabolomics, mRNA abundance, protein abundance, and phosphorylation status. In brief, MAC-T cells were cultured overnight without serum and then treated for $12 \mathrm{~h}$ (Li et al., 2017) with 5 treatments ( $\mathrm{n}=5$ replicates/treatment) in medium without serum. A lactogenic medium was used for treatment analyses according to a previous publication from one of our laboratories (Kadegowda et al., 2009), except that minimum essential medium/Earle's balanced salts HyQ was replaced by high-glucose Dulbecco's modified Eagle's medium without EAA (custom made by Gibco, Thermo Fisher Scientific, Waltham, MA). Individual EAA (L-isomer, Sigma-Aldrich, St. Louis, MO) were added into the custom high-glucose Dulbecco's modified Eagle's medium.

The control medium contained the ideal profile of Lys:Met and fixed ratios of other EAA (IPAA, Lys: Met 2.9:1; Lys:Thr 1.8:1; Lys:His 2.38:1; Lys:Val 1.23:1; Lys:Ile 1.45:1; Lys:Leu 0.85:1; Lys:Arg 2.08:1) and treatment medium was prepared using IPAA plus different concentrations of Thr, Ile, Val, and Leu to achieve Lys:Thr 1.3:1 (LT1.3), Lys:Ile 1.29:1 (LI1.29), Lys:Val 1.12:1 (LV1.12), and Lys:Leu 0.78:1 (LL0.78; Table 1). The IPAA was designed to resemble recommendations from NRC (2001) and Haque et al. (2012, 2013). The lower ratios of Lys to Val, Lys to Ile, and Lys to Leu were to enhance Val, Ile, and Leu supply to a level demonstrated to elicit positive responses in milk protein (Haque et al., 2012, 2015). Similarly, the chosen ratio of Thr to Phe was to maintain the ratio as close as possible to the theoretical optimal $(\sim 1.0: 1.0)$ as discussed in Haque et al. (2012). The Lys to Thr ratios were chosen based on data from Prizant and Barash (2008). By changing the supply of these AA while holding Lys constant, we sought to determine individual effects that might help explain in vivo responses in the literature (Haque et al., 2012, 2013, 2015).

\section{RNA Extraction and Real-Time PCR Analysis}

The RNA extraction and real-time PCR was performed exactly as described previously (Bionaz and Loor, 2008). In brief, total RNA was obtained using the RNeasy Mini columns (Qiagen, Valencia, CA). The 
Table 1. Calculated AA composition of experimental treatments

\begin{tabular}{|c|c|c|c|c|c|}
\hline \multirow[b]{2}{*}{ Item } & \multicolumn{5}{|c|}{ Treatment $^{1}$} \\
\hline & IPAA & LT1.3 & LI1.29 & LV1.12 & LL0.78 \\
\hline Lys $(\mu \mathrm{g} / \mathrm{mL})$ & 175 & 175 & 175 & 175 & 175 \\
\hline Met $(\mu \mathrm{g} / \mathrm{mL})$ & 60 & 60 & 60 & 60 & 60 \\
\hline Lys/Met & $2.9: 1$ & $2.9: 1$ & $2.9: 1$ & $2.9: 1$ & $2.9: 1$ \\
\hline Thr $(\mu \mathrm{g} / \mathrm{mL})$ & 97 & 125 & 97 & 97 & 97 \\
\hline Phe $(\mu \mathrm{g} / \mathrm{mL})$ & 93 & 119 & 93 & 93 & 93 \\
\hline Thr/Phe & $1.05: 1$ & 1.05:1 & $1.05: 1$ & $1.05: 1$ & $1.05: 1$ \\
\hline Lys/Thr & $1.8: 1$ & $1.3: 1$ & $1.8: 1$ & $1.8: 1$ & $1.8: 1$ \\
\hline His $(\mu \mathrm{g} / \mathrm{mL})$ & 74 & 74 & 74 & 74 & 74 \\
\hline Lys/His & $2.38: 1$ & $2.38: 1$ & $2.38: 1$ & $2.38: 1$ & $2.38: 1$ \\
\hline Val $(\mu \mathrm{g} / \mathrm{mL})$ & 142 & 142 & 142 & 156 & 142 \\
\hline Lys/Val & $1.23: 1$ & $1.23: 1$ & $1.23: 1$ & $1.12: 1$ & $1.23: 1$ \\
\hline Ile $(\mu \mathrm{g} / \mathrm{mL})$ & 121 & 121 & 136 & 121 & 121 \\
\hline Lys/Ile & $1.45: 1$ & $1.45: 1$ & $1.29: 1$ & $1.45: 1$ & $1.45: 1$ \\
\hline Leu $(\mu \mathrm{g} / \mathrm{mL})$ & 206 & 206 & 206 & 206 & 225 \\
\hline Lys/Leu & $0.85: 1$ & $0.85: 1$ & $0.85: 1$ & $0.85: 1$ & $0.78: 1$ \\
\hline $\operatorname{Arg}(\mu \mathrm{g} / \mathrm{mL})$ & 84 & 84 & 84 & 84 & 84 \\
\hline Lys/Ärg & $2.08: 1$ & $2.08: 1$ & $2.08: 1$ & $2.08: 1$ & $2.08: 1$ \\
\hline $\operatorname{Trp}(\mu \mathrm{g} / \mathrm{mL})$ & 16 & 16 & 16 & 16 & 16 \\
\hline Cys $(\mu \mathrm{g} / \mathrm{mL})$ & 63 & 63 & 63 & 63 & 63 \\
\hline $\mathrm{Gln}(\mu \mathrm{g} / \mathrm{mL})$ & 584 & 584 & 584 & 584 & 584 \\
\hline Gly $(\mu \mathrm{g} / \mathrm{mL})$ & 30 & 30 & 30 & 30 & 30 \\
\hline Ser $(\mu \mathrm{g} / \mathrm{mL})$ & 42 & 42 & 42 & 42 & 42 \\
\hline $\operatorname{Tyr}(\mu \mathrm{g} / \mathrm{mL})$ & 104 & 104 & 104 & 104 & 104 \\
\hline
\end{tabular}

RNA concentrations and integrity were determined by the NanoDrop ND-1000 spectrophotometer (NanoDrop Technologies, Wilmington, DE) and Agilent 2100 Bioanalyzer (Agilent Technologies, Santa Clara, CA). Samples for subsequent analysis had an RNA integrity number $>8.0$, and a portion of each was diluted to 100 $\mathrm{ng} / \mu \mathrm{L}$ with RNase-free water before cDNA synthesis. One hundred nanograms of RNA was used for cDNA synthesis, and the quantitative PCR was performed as described previously. Primers were designed and verified based on established protocols in the Loor laboratory (Bionaz and Loor, 2011). Three control genes (GADPH, UXT, and RPS9) were used for normalization of target gene abundance. The primer information is reported in Supplemental Table S1 (https://doi.org/ 10.3168/jds.2017-13707).

\section{Western Blot}

Protein samples from each of the 5 replicates per treatment was used for Western blot analysis as previously described with modifications (Hosseini et al., 2015). Each biological replicate $(\mathrm{n}=5$ /treatment) had 1 technical replicate such that 5 biological replicates were run in the same gel along with the target protein and the internal control (GAPDH). Therefore, the 5 technical replicates were run in 5 different gels. Twenty micrograms of total protein and $4 \times$ Laemmli sample buffer (\#161-0747, Bio-Rad, Hercules, CA) were mixed at a ratio of $3: 1$ (wt:vol) and denatured at $95^{\circ} \mathrm{C}$ for 10 min. Proteins were separated using the 10\% SDS/ PAGE with $120 \mathrm{~V}$ for 120 min. Electrotransfer to PVDF membranes (\#162-0261, Bio-Rad) was performed in the Trans-Blot SD Semi-Dry Electrophoretic Transfer Cell (\#170-3940, Bio-Rad), and PVDF membranes were incubated with primary antibody overnight at $4^{\circ} \mathrm{C}$ after blocking for $1 \mathrm{~h}$ with $5 \%$ skim milk at room temperature. The PVDF membranes were then washed 6 times (5 min/time) and incubated with goat polyclonal secondary antibody for $1 \mathrm{~h}$ at room temperature before washing. The visualization of PVDF membranes was performed using the ChemiDoc MP System (Bio-Rad) with Clarity Western ECL Substrate (\#170-5060, BioRad) reagent. The Image Lab software (version 3.0) was used for relative quantification of proteins (arbitrary units). All Western data were standardized by the internal reference protein in the same well (e.g., target protein abundance $=$ total target protein intensity/ GAPDH intensity). The phosphorylation status was calculated as the ratio of phosphorylated protein/total protein. The antibody list is reported in Supplemental Table S2 (https://doi.org/10.3168/jds.2017-13707). The GAPDH was used to normalize target protein abundance. 


\section{Promoter Region-Specific DNA Methylation}

The DNA extraction and methylation analysis of MTORC1 and CSN1S1 were performed as described previously (Osorio et al., 2016). In brief, DNA extraction and cleaning was performed with the DNeasy Blood and Tissue Kit (catalog no. 69504, Qiagen) and Genomic DNA Clean and Concentrator Kit (catalog no. D4013, Zymo Research, Irvine, CA). Identification of gene promoter region specific methylation containing CpG islands was based on the OneStep qMethyl kit (catalog no. D5310, Zymo Research) protocol. Nonmethylated DNA (negative control) was obtained by whole-genome amplification, and methylated control (positive control) was obtained by methylase reaction. The primers used in the present study were designed to cover the sections in the promoter region. Primers for the promoter region of MTORC1 and CSN1S1 covered from $-1,802$ to $-1,631 \mathrm{bp}$ and from -860 to -618 bp, and contained $2 \mathrm{CpG}$ sites specific for the Methylation Sensitive Restriction Enzyme in the OneStep qMethyl kit. The primer list for methylation is reported in Supplemental Table S3 (https://doi.org/10.3168/jds .2017-13707).

\section{GC-MS Analysis}

The GC-MS analysis was based largely on a previous report (Levengood et al., 2015). Briefly, the extraction of metabolites was performed by sonicating each replicate in $1 \mathrm{~mL}$ of methanol (70\%) 5 times (each time for $1 \mathrm{~min}, 30 \mathrm{~s}$ on, then $30 \mathrm{~s}$ off) with the QSonica Q700 homogenizer (QSonica LLC, Newton, CT). Before derivatization, $5 \mu \mathrm{L}$ of the internal standard (hentriacontanoic acid, $10 \mathrm{mg} / \mathrm{mL}$ ) was added to each sample supernatant. Metabolomics analysis was performed using a GC-MS system (Agilent Inc.) consisting of an Agilent 7890 gas chromatograph, an Agilent 5975 MSD and a HP 7683B autosampler. All spectra chromatogram peaks were compared with the AMDIS 2.71 (NIST, Gaithersburg, MD) software and a custom-built database. Before data mining, those peaks that could not be matched with the available database were removed. Subsequently, the normalization of all data using the internal standard and cell dry weight was performed. Instrument variability across all samples was within the accepted range of $5 \%$.

\section{Data Analysis}

Chemometric models including supervised partial least-squares discriminant analysis and orthogonal partial least-squares discriminant analysis were obtained with MetaboAnalyst 3.0 (Xia and Wishart, 2011) us- ing log-transformed and autoscaled data. Metabolites with $30 \%$ and more of missing data were removed from analysis; the missing values (less than 30\%) for a particular metabolite were imputed with the observed minimum detection value, assuming their level was below the instrument detection limit. A probability level of $P<0.05$ was considered statistically significant. Statistical models were validated by 10 -fold crossvalidation and response permutation with 500 random reclassifications. A regression coefficient plot with $95 \%$ jackknifed confident intervals was used to determine which metabolites drove observed clustering patterns. Parameters $R^{2} Y$ (linear regression model of predicted and observed variables) and $\mathrm{Q}^{2}$ (quality assessment statistics) are more than 0.5 indicating a robust model with prominent predictive ability. Metabolites with variable importance for projection (VIP) values exceeding 1.5 were selected as the significantly different metabolites (Storey, 2002; Wiklund et al., 2008; Issaq and Veenstra, 2013).

Western blot data with nonnormal distribution and all mRNA abundance data were $\log _{2}$ transformed to obtain a normal distribution before statistical analysis. Statistical analysis was performed using the MIXED model in SAS (version 9.3, SAS Institute Inc., Cary, NC) with ratios of Lys to Thr, Ile, Val, and Leu as fixed effects and cell culture as the random effect. The control group in the present study was the same as that in Dong et al. (2018) in which the specific objective was to evaluate the effect of increasing the supply of Met while holding Lys constant on the same gene and protein targets that are reported herein. Treatment means were compared using the PDIFF statement in SAS after correction using Tukey's. Significance was declared at a PDIFF Tukey-adjusted $P<0.05$.

\section{RESULTS}

\section{Metabolomics}

In total 162 compounds were identified and quantified by GC-MS, the list of metabolites is reported in Supplemental Table S4 (https://doi.org/10.3168/jds .2017-13707). The partial least-squares discriminant analysis and orthogonal partial least-squares discriminant analysis showed significantly separated clusters between IPAA and LT1.3, LI1.29, LV1.12, and LL0.78 (Supplemental Figures S1 and S2; https://doi.org/10 $.3168 /$ jds.2017-13707). The $\mathrm{R}^{2} \mathrm{Y}$ and $\mathrm{Q}^{2}$ values $>0.5$ are both indicative of proper reliability of the model. The $R^{2} Y$ was greater than 0.992 in all comparisons, indicating that the models had good reliability. Most of $\mathrm{Q}^{2}$ values were at least 0.51 indicating the models had outstanding predictive ability (Supplemental Figures 
S1 and S2; https://doi.org/10.3168/jds.2017-13707). The top 15 significantly different metabolites between IPAA and LT1.3, LI1.29, LV1.12, and LL0.78 (VIP $>1.5, P<0.05$ ) are depicted in the VIP plots (Figure $1)$. The red- and green-colored squares denote a high or low concentration.

Compared with IPAA, culture with LT1.3 increased the concentration of certain EAA (Leu, Thr) and the NEAA Glu, Gln, Asp, Gly, and Ser. Compared with IPAA, an increase in availability of Ile (LI1.29) led to higher Leu concentration and concentration of Pro,
Asp, Glu, and Gln. Relative to IPAA, culture with LV1.12 also increased the concentration of various EAA (His, Met, Ile, and Leu) and NEAA (Gln, Glu, Ser, Gly, and Asp).

In addition to changes in AA concentrations, all of the treatment groups (LT1.3, LI1.29, LV1.12, and LL0.78) had greater concentrations of uric acid relative to IPAA. Compared with IPAA, culture with LT1.3 and LV1.12 led to greater concentration of phosphoric acid, but incubation with LI1.29 and LL0.78 decreased the concentration of phosphoric acid. Compared with
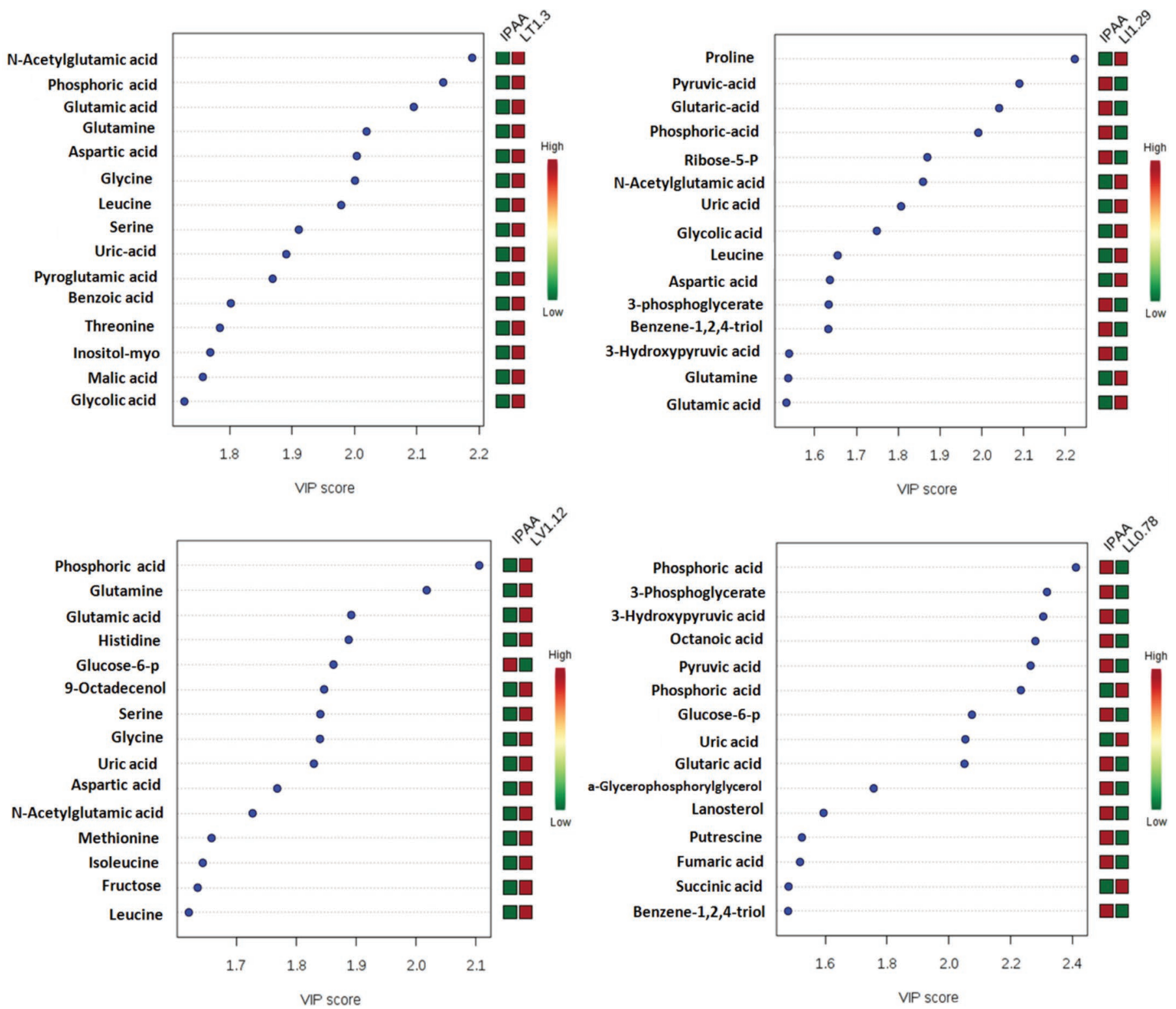

Figure 1. Metabolites ranked by variable importance in projection (VIP) analysis in response to culturing mammary epithelial cells with different EAA ratios: IPAA = ideal profile of Lys:Met and fixed ratio of other EAA; LT1.3 = Lys:Thr ratio of 1.3:1; LI1.29 = Lys:Ile ratio of 1.29:1; LV1.12 = Lys:Val ratio of 1.12:1; LL0.78 = Lys:Leu ratio of 0.78:1. 
IPAA, culture with LV1.12 and LL0.78 decreased the concentration of glucose-6-phosphate. A lower concentration of pyruvic acid and 3-phosphoglycerate was observed with the supplementation of Ile and Leu relative to IPAA.

\section{mRNA Abundance}

The effects of EAA ratios on mRNA abundance of $\mathrm{AA}$ transporters and $\beta$-casein (CSN2) are shown in Table 2. Compared with IPAA, all treatments resulted in greater $(P<0.01)$ mRNA abundance of SLC3A2. Compared with IPAA, treatment LL0.78 had greater $(P<0.05)$ mRNA abundance of SLC36A1, SLC38A9, and SLC38A2. Higher $(P<0.05)$ mRNA abundance of SLC38A9 also was observed with treatment LT1.3 compared with IPAA.

Treatment LV1.12 increased $(P<0.01)$ the mRNA abundance of SLC38A9 relative to IPAA. However, compared with IPAA, treatment LI1.29 decreased ( $P$ $<0.05)$ the mRNA abundance of SLC7A5, SLC38A2, and $S L C 43 A 1$. Compared with IPAA, a lower mRNA abundance of $S L C 43 A 1$ was also observed in treatment LT1.3 and treatment LV1.12. Relative to IPAA, treatment LV1.12 was with the significant trend $(P=0.15)$ to increase mRNA abundance of CSN2. However, treatment LI1.29 tended to decrease the mRNA abundance of CSN2.

\section{Protein Abundance and Phosphorylation Status of mTOR Pathway}

The effects of EAA ratios on protein abundance and phosphorylation status of signaling proteins in the mTOR pathway are reported in Table 3. Compared with IPAA, an increase in both Ile (LI1.29) and Val (LV1.12) resulted in greater $(P<0.01)$ phosphoryla- tion ratio of mTORC1. However, the increase in Thr (LT1.3) led to lower $(P<0.01)$ phosphorylation ratio of mTORC1. Compared with IPAA, phosphorylation ratio of Akt increased $(P<0.01)$ only in LV (1.12). An increase $(P<0.05)$ in phosphorylation ratio of RPS6 was observed with both Val (1.12) and Leu (LL0.78) compared with IPAA. An increasing trend of S6K1 phosphorylation ratio was also observed in both Val (1.12) and Leu (LL0.78) relative to IPAA. Compared with IPAA, the phosphorylation ratio of 4EBP1 was increased $(P<0.05)$ by LT1.3. Compared with IPAA, the phosphorylation ratio of eIF2 $\alpha$ was decreased $(P<$ 0.01 ) with the supplementary of Ile, Val, and Leu. No significant change was observed in the phosphorylation ratio of eEF2 relative to IPAA.

\section{Promoter Region-Specific DNA Methylation}

The effects of EAA ratios on promoter regionspecific DNA methylation of mTORC1 and $\alpha_{\mathrm{S}_{1} \text {-casein }}$ (CSN1S1) are reported in Table 4 . The degree of methylation of MTORC1 was below $2 \%$, but that of CSN1S1 was greater than $80 \%$ regardless of treatment. Compared with IPAA, an increase in Ile, Val, and Leu led to greater mRNA abundance $(P<0.01)$ of $C S N 1 S 1$. The LV1.12 has great potential to increase $(P=0.15)$ the methylation of CSN1S1 relative to IPAA. No significant difference was observed in mRNA abundance and methylation of mTORC1 relative to IPAA.

\section{DISCUSSION}

\section{Intracellular Metabolism}

Thr, Ser, and Gly Metabolism. Although the exact mechanisms are unknown, in vivo and in vitro research revealed that Thr could promote milk protein

Table 2. Effects of different EAA ratios on mRNA abundance (log-scale) of AA transporters and $\beta$-casein $(C S N 2)^{1}$

\begin{tabular}{|c|c|c|c|c|c|c|c|}
\hline \multirow[b]{2}{*}{ Gene } & \multicolumn{5}{|c|}{ Treatment $^{2}$} & \multirow[b]{2}{*}{ SEM } & \multirow[b]{2}{*}{$P$-value } \\
\hline & IPAA & LT1.3 & LI1.29 & LV1.12 & LL0.78 & & \\
\hline$\overline{S L C 3 A 2}$ & $0.32^{\mathrm{b}}$ & $0.63^{\mathrm{a}}$ & $0.93^{\mathrm{a}}$ & $0.84^{\mathrm{a}}$ & $0.77^{\mathrm{a}}$ & 0.14 & $<0.001$ \\
\hline SLC7A5 & $1.14^{\mathrm{ab}}$ & $1.10^{\mathrm{b}}$ & $0.76^{\mathrm{c}}$ & $1.11^{\mathrm{ab}}$ & $1.25^{\mathrm{a}}$ & 0.03 & $<0.001$ \\
\hline SLC36A1 & $1.11^{\mathrm{b}}$ & $1.17^{\mathrm{ab}}$ & $0.98^{\mathrm{b}}$ & $1.18^{\mathrm{ab}}$ & $1.39^{\mathrm{a}}$ & 0.06 & 0.002 \\
\hline SLC38A2 & $1.26^{\mathrm{bc}}$ & $1.38^{\mathrm{ab}}$ & $0.94^{\mathrm{d}}$ & $1.17^{\mathrm{c}}$ & $1.45^{\mathrm{a}}$ & 0.04 & $<0.001$ \\
\hline SLC $38 A 9$ & $1.05^{\mathrm{b}}$ & $1.31^{\mathrm{a}}$ & $0.91^{\mathrm{b}}$ & $1.30^{\mathrm{a}}$ & $1.42^{\mathrm{a}}$ & 0.05 & $<0.001$ \\
\hline$S L C 43 A 1$ & $1.20^{\mathrm{a}}$ & $0.99^{\mathrm{bc}}$ & $0.87^{\mathrm{c}}$ & $1.00^{\mathrm{b}}$ & $1.23^{\mathrm{a}}$ & 0.04 & $<0.001$ \\
\hline CSN2 & $1.56^{\mathrm{ab}}$ & $1.58^{\mathrm{ab}}$ & $1.15^{\mathrm{b}}$ & $2.08^{\mathrm{a}}$ & $1.67^{\mathrm{ab}}$ & 0.17 & 0.006 \\
\hline
\end{tabular}


Table 3. Effects of different EAA ratios on protein abundance and phosphorylation status of signaling proteins ${ }^{1}$

\begin{tabular}{|c|c|c|c|c|c|c|c|}
\hline Item & \multicolumn{5}{|c|}{ Treatment $^{2}$} & SEM & $P$-value \\
\hline \multicolumn{8}{|l|}{ Total protein ${ }^{3}$} \\
\hline mTORC1 & $0.15^{\mathrm{b}}$ & $1.43^{\mathrm{a}}$ & $0.27^{\mathrm{b}}$ & $0.11^{\mathrm{b}}$ & $0.28^{\mathrm{b}}$ & 0.10 & $<0.001$ \\
\hline 4EBP1 & $0.72^{\mathrm{bc}}$ & $0.57^{\mathrm{c}}$ & $1.83^{\mathrm{ab}}$ & $1.94^{\mathrm{a}}$ & $1.26^{\mathrm{abc}}$ & 0.28 & 0.006 \\
\hline S6K1 & $4.14^{\mathrm{a}}$ & $2.17^{\mathrm{b}}$ & $1.75^{\mathrm{b}}$ & $1.91^{\mathrm{b}}$ & $1.01^{\mathrm{b}}$ & 0.34 & $<0.001$ \\
\hline EEF2 & 0.60 & 0.61 & 1.08 & 0.88 & 0.85 & 0.15 & 0.150 \\
\hline \multicolumn{8}{|c|}{ Phosphorylated $(\mathrm{p})$ protein } \\
\hline $\mathrm{p}-\mathrm{Akt}$ & 0.54 & 0.94 & 0.61 & 0.50 & 1.35 & 0.26 & 0.155 \\
\hline p-mTORC1 & $1.04^{\mathrm{c}}$ & $2.47^{\mathrm{b}}$ & $3.41^{\mathrm{a}}$ & $2.57^{\mathrm{b}}$ & $1.48^{\mathrm{c}}$ & 0.14 & $<0.001$ \\
\hline p-4EBP1 & $1.50^{\mathrm{b}}$ & $2.23^{\mathrm{a}}$ & $6.40^{\mathrm{a}}$ & $6.33^{\mathrm{a}}$ & $3.30^{\mathrm{ab}}$ & 1.05 & 0.007 \\
\hline p-S6K1 & $0.24^{\mathrm{a}}$ & $0.14^{\mathrm{abc}}$ & $0.08^{\mathrm{c}}$ & $0.18^{\mathrm{ab}}$ & $0.10^{\mathrm{bc}}$ & 0.02 & $<0.001$ \\
\hline p-RPS6 & $1.82^{\mathrm{b}}$ & $4.78^{\mathrm{a}}$ & $4.39^{\mathrm{a}}$ & $4.45^{\mathrm{a}}$ & $2.21^{\mathrm{b}}$ & 0.38 & $<0.001$ \\
\hline p-4EBP1/4EBP1 & $2.11^{\mathrm{b}}$ & $4.54^{\mathrm{a}}$ & $3.57^{\mathrm{ab}}$ & $3.44^{\mathrm{ab}}$ & $2.54^{\mathrm{ab}}$ & 0.48 & 0.018 \\
\hline $\mathrm{p}-\mathrm{S} 6 \mathrm{~K} 1 / \mathrm{S} 6 \mathrm{~K} 1$ & 0.06 & 0.07 & 0.05 & 0.09 & 0.10 & 0.01 & 0.026 \\
\hline p-RPS6/RPS6 & $0.25^{\mathrm{c}}$ & $0.47^{\mathrm{bc}}$ & $0.53^{\mathrm{bc}}$ & $1.29^{\mathrm{a}}$ & $0.61^{\mathrm{b}}$ & 0.08 & $<0.001$ \\
\hline p-EIF $2 \alpha /$ EIF $2 \alpha$ & $0.55^{\mathrm{a}}$ & $0.22^{\mathrm{ab}}$ & $0.09^{\mathrm{bc}}$ & $0.04^{\mathrm{c}}$ & $0.07^{\mathrm{c}}$ & 0.02 & $<0.001$ \\
\hline p-EEF $2 / E E F 2$ & $18.22^{\mathrm{ab}}$ & $24.55^{\mathrm{a}}$ & $9.04^{\mathrm{b}}$ & $26.79^{\mathrm{a}}$ & $20.21^{\mathrm{ab}}$ & 3.13 & 0.006 \\
\hline
\end{tabular}

${ }^{\mathrm{a}-\mathrm{d}}$ Means in a row without a common superscript differ, $P<0.05$.

${ }^{1}$ Data are LSM and SEM ( $\mathrm{n}=5$ replicates per treatment).

${ }^{2}$ IPAA = ideal profile of Lys:Met and fixed ratio of other EAA according to Table 1; LT1.3 = Lys:Thr ratio of 1.3:1; LI1.29 = Lys:Ile ratio of 1.29:1; LV1.12 = Lys:Val ratio of 1.12:1; LL0.78 = Lys:Leu ratio of 0.78:1.

${ }^{3} \mathrm{Akt}=$ serine/threonine kinase $\mathrm{B} ; \mathrm{mTORC} 1=$ mammalian target of rapamycin complex $1 ;$ 4EBP1 = eukaryotic initiation factor $4 \mathrm{E}$ binding protein 1; S6K1 = ribosomal protein S6 kinase; RPS6 = ribosomal protein S6; EIF2 $\alpha=\alpha$ subunit of eukaryotic translation initiation factor 2; $\mathrm{EEF} 2$ = eukaryotic translation elongation factor 2.

synthesis by increasing mTORC1 phosphorylation (Arriola Apelo et al., 2014; Zhou et al., 2015). The fact that Thr uptake by mammary gland is in excess of its output in milk protein (Lapierre et al., 2012) indicates this AA is likely metabolized to other compounds. The enzyme threonine dehydrogenase metabolizes $\mathrm{Thr}$ to Gly, and its activity is positively correlated with Thr concentration (Floc'h et al., 1996; Davis and Austic, 1997; Lee et al., 2014). If metabolism of supplemental Thr enhanced Gly synthesis via threonine dehydrogenase, it could have had a positive effect on regulation of cellular proliferation and the synthesis of Ser as part of the one-carbon metabolism pathway (Han et al. 2013; Tang et al., 2014). It is well-established that Ser/

Table 4. Effects of different EAA ratios on promoter region-specific DNA methylation of mammalian target of rapamycin complex $1(m T O R C 1)$ and $\alpha_{S_{1}}$-casein $(C S N 1 S 1)^{1}$

\begin{tabular}{|c|c|c|c|c|c|c|c|}
\hline \multirow[b]{2}{*}{ Gene } & \multicolumn{5}{|c|}{ Treatment $^{2}$} & \multirow[b]{2}{*}{ SEM } & \multirow[b]{2}{*}{$P$-value } \\
\hline & IPAA & LT1.3 & LI1.29 & LV1.12 & LL0.78 & & \\
\hline \multicolumn{8}{|l|}{ MTORC1 } \\
\hline mRNA abundance & 1.09 & 1.11 & 1.04 & 1.20 & 1.05 & 0.06 & 0.16 \\
\hline \% Methylation & 1.77 & 1.96 & 1.80 & 1.71 & 1.56 & 0.18 & 0.49 \\
\hline \multicolumn{8}{|l|}{ CSN1S1 } \\
\hline mRNA abundance & $0.10^{\mathrm{d}}$ & $0.19^{\mathrm{cd}}$ & $0.28^{\mathrm{bc}}$ & $0.66^{\mathrm{a}}$ & $0.59^{\mathrm{ab}}$ & 0.12 & $<0.001$ \\
\hline \% Methylation & 82.2 & 92.2 & 84.0 & 92.6 & 90.6 & 3.18 & 0.06 \\
\hline
\end{tabular}


Gly contributes to cellular metabolism through the Gly cleavage system, refueling the one-carbon metabolism pathway. Taken together, results suggest that an increase in Thr supply resulting in higher concentration of Thr, Gly, and Ser is an indication that the LT1.3 treatment stimulated Thr-Gly-Ser metabolism; however, the fact that this treatment did not upregulate CSN2 and CSN1S1, and actually decreased phosphorylation of mTORC1 seems to suggest a limited capacity for enhancing milk protein synthesis beyond what can be achieved with IPAA. We speculate that the lack of response to Thr was due to its limited intramammary catabolism (Lapierre et al., 2012),

Branched-Chain AA Metabolism. Although Ile and Leu have been demonstrated to independently regulate the activity of $\mathrm{mTORC} 1$ and protein synthesis in bovine mammary cells (BMEC; Appuhamy et al., 2012); to our knowledge, there are no reports on the effect of ratio of Lys to Leu or Lys to Ile on the regulation of milk protein synthesis. Furthermore, compared with a theoretically optimal AA mixture, decreasing Val relative to Lys reduced $\beta$-casein mRNA abundance (Li et al., 2017). Therefore, an important objective in the present study was to evaluate the individual effects of the branched-chain amino acids (BCAA).

The BCAA are typically taken up by mammary gland in excess of the amount secreted into milk (Derrig et al., 1974; Clark et al., 1977; Wohlt et al., 1977). The excess BCAA are mostly degraded to intermediary metabolites that could indirectly regulate protein synthesis (Zhang, 2017). Therefore, it is plausible that even after supplementation with Ile, Val, or Leu their concentrations are not significantly increased, except for an increase in Leu in response to LI1.29 and LV1.12 (also LT1.3), which was the case in the present study.

Work with bovine mammary tissue revealed that the BCAA can be metabolized to a small but significant extent to Glu and Asp in addition to $\beta-\mathrm{OH}$-isobutyrate (with Val), isovalerate (with Leu), and methylmalonate (with Ile; Wohlt et al., 1977). Other metabolites produced during incubation with Val included $\alpha$-ketoisovalerate and isobutyrate. Incubation with Leu also resulted in production of $\alpha$-ketoisocaproate, acetate, and citrate. Among the BCAA, incubation with Ile led to the smallest concentrations of $\alpha$-keto- $\beta$ methylvalerate, propionate, and acetate (Wohlt et al., 1977).

Clearly, the current GC-MS approach allowed for higher resolution in terms of intermediate metabolites produced during the metabolism of BCAA. Although it is not intuitive how most of the top metabolites identified with increasing supplementation of Val could play a role in milk protein synthesis regulation, the LV1.12 treatment in this study was associated with the high- est phosphorylation of mTORC1, Akt, and RPS6, and upregulation of CSN2 and CSN1S1. Based on previous data, we speculate that Val could regulate mTORC1 activity through Rag proteins (related small guanosine triphosphatases), which function to enhance the interaction of mTORC1 with its activator Rhed proteins (Ras homolog enriched in brain; Sancak et al., 2008).

Gln and Glu Metabolism. Glutamine and Glu are at the center of amino nitrogen interchanges and hence play important roles in AA metabolism (Kelly and Stanley, 2001). These NEAA are quantitatively the most abundant in milk protein (Derrig et al., 1974). Because of the markedly low uptake by the mammary gland relative to secretion in milk protein, it is thought that Gln and Glu are synthesized by the mammary gland (Guinard et al., 1994). Activity of glutaminase and glutamine synthetase catalyze the interconversion of Gln to Glu in BMEC (Manjarin et al., 2014), but the importance of Gln is underscored by the fact that Glu cannot easily be transported across plasma membranes (Newsholme et al., 2003). In addition, bi-directional flux of Gln across cellular plasma membranes (via SLC7A5/SLC3A2) in response to EAA availability (and Leu in particular) appears to be a key factor in the activation of mTORC1 (Nicklin et al., 2009). The high concentration of Gln in response to LT1.3, LI1.29, and LV1.12 agrees with the greater concentration of Leu suggesting a similar mechanism of control of mTORC1 in mammary cells. Furthermore, the high VIP score for Glu in response to LV1.12 agrees with the highest phosphorylation of mTORC1 and abundance of CSN2 and CSN1S1.

The high concentration of Glu observed in response to LT1.3, LI1.29, and LV1.12 indicated a higher degree of AA utilization through reducing AA oxidation, a response that might have an effect on milk protein synthesis. Compared with Gln, Glu appears to be more important in terms of oxidation because it can directly donate or receive amino groups. Glutamate dehydrogenase and amino transferase are important in the interconversion of Glu and 2-oxoglutarate (Brosnan and Brosnan, 2013). In fact, it is well known that 2-oxoglutarate is an intermediate in the catabolism of most AA and can spare EAA from oxidation via reamination with Glu to form other AA (Lobley et al., 2001). Most EAA are potential oxo-acid acceptors, and in particular Met and Phe are confirmed as the preferred acceptors of 2-oxoglutarate (Blarzino et al., 1994).

Met and His Metabolism. Methionine and His are both considered as limiting AA partly because deficiencies of Met and His could decrease the availability of other EAA (Kim et al., 1999; Manjarin et al., 2014). The higher intracellular concentration of Met and His in response to LV1.12 indicated that an increase in Val 
based on the IPAA might further promote the uptake of EAA such as Met and His. It has been demonstrated that enhancing the postruminal supply of Met, Lys, and His could promote milk protein synthesis (Giallongo et al., 2016). Furthermore, at least in vitro, His upregulated milk protein gene expression partly through increasing the activity of the mTOR pathway (Gao et al., 2015). Therefore, it is reasonable to speculate that a higher intracellular concentration of both Met and His when the supplementation of Val increases may have a positive effect on milk protein synthesis. Because the AA transporters examined did not uniquely respond to an increase in Val availability, the mechanism whereby this AA might stimulate the preferential uptake of Met and His is difficult to explain. Although we did not detect an increase in histamine, it is possible that the increase in His in response to LV1.12 would indirectly affect the growth of BMEC (Davio et al., 1994) through the conversion of His to histamine. It also is possible that an increase in His would affect flux through the histidine/histamine/S-adenosylmethionine/ $N$-methylhistamine pathway and elicit an effect on methyl group metabolism (Rai et al., 2014).

Arg Metabolism. Although there was no significant change in Arg concentration across treatments, the increase in concentration of $N$-acetylglutamate in response to enhanced availability of Thr, Ile, and Val was suggestive of potential alterations in Arg metabolism. Activity of carbamoylphosphate synthetase I, the ratelimiting enzyme for Arg synthesis in the urea cycle, is allosterically activated by $N$-acetylglutamate (Grisolia and Cohen, 1953). The fact that we did not detect increases in urea, ornithine, or putrescine in response to LT1.3, LI1.29, and LV1.12 but detected a lower intracellular concentration of putrescine in LL0.78 seems to suggest that an increase in Thr, Ile, Val, and Leu relative to IPAA might favor the utilization of Arg for milk protein synthesis via different mechanisms. For instance, the fact that putrescine (an intermediate metabolite derived from the arginine-ornithine-putrescine metabolism pathway) could promote milk protein synthesis in BMEC (Wang et al., 2017) might partly explain the lack of increase in mTORC1 phosphorylation in response to LL0.78. However, the fact that various AA transporters (SLC3A2, SLC7A 5, SLC36A1, SLC38A2, SLC38A9) and CSN1S1 were upregulated with LL0.78 compared with IPAA seems to suggest that increased Leu availability could regulate milk protein synthesis by different mechanisms. Another possibility given the lack of response in mTORC1 phosphorylation in response to LL0.78 compared with IPAA is that the increase in Leu created an imbalance of EAA.

\section{AA Transport}

In the present experiment, we measured transcription of 6 AA transporters (SLC3A2, SLC7A5, SLC $36 A 1$, SLC38A2, SLC38A9, and SLC43A1) associated with mTORC1 activity and the regulation of AA transport (Heublein et al., 2010; Fotiadis et al., 2013; Broer, 2014). The SLC3A2 and SLC7A5 constitute heteromeric amino acid transporters (HAT), responsible for the transport of various types of AA (Palacin and Kanai, 2004). The SLC7A5 functions as the transport competent subunit of the HAT complex (Napolitano et al., 2015), whereas SLC3A2 is responsible for the localization of HAT to the plasma membrane and does not pump AA into or out of cells (Wang et al., 2012; Napolitano et al., 2015). Therefore, we speculate that the upregulation of SLC3A2 due to the increase in Thr, Ile, Val, and Leu relative to IPAA could promote AA transport and direct the HAT to the cell membrane. Despite the lack of effect on mTORC1 phosphorylation, in contrast to other treatments, the upregulation of SLC36A1, SLC38A2, and SLC38A9 in response to LL0.78 was suggestive of some specificity toward Leu. From a mechanistic standpoint, the lack of significant change in intracellular concentration of Gln when the supply of Leu increased could be a reason for the lack of response on mTORC1. Previous data indicated that by promoting the influx of Leu through a bidirectional transport mechanism, Gln can activate mTORC1 (Zheng et al., 2016). A deficiency in Gln supply could trigger the uptake of Leu (Chen et al., 2014); thus, we speculate that in an AA-sufficient state there is a different mechanism whereby Leu can regulate mTOR pathway activity.

The protein SLC38A9 is a new member of the SLC38 transporter family that plays a role in the pumping of neutral AA out of the cell (Broer, 2014). Recent studies have reported that SLC38A9 could indirectly participate in the regulation of $\mathrm{mTORC} 1$ activation as a component of the regulator-RAG GTPase machinery (Rebsamen et al., 2015; Wang et al., 2015). To our knowledge, no data have been published linking EAA ratios and SLC38A9 activity in the context of milk protein synthesis in BMEC.

Overall, data from the present study indicate that an increase in Thr, Val, and Leu could affect the activation of mTORC1 and milk protein synthesis potentially through the regulation of AA transporter abundance. However, because a low protein or AA level could also induce the increase in mRNA abundance of AA transporters (Karasov et al., 1987; Wang et al., 2017), it is necessary to further test whether these treatments 
with an increase in Val and Ile based on the IPAA could enhance the activity of mTOR pathway and milk protein synthesis.

\section{mTOR Signaling Pathway Regulation}

The activity of the mTOR pathway is partly under the regulation of EAA availability (Proud, 2004). The mTORC1, as a protein kinase, is at the core of a signaling pathway that regulates protein synthesis by integrating intracellular AA availability and endocrine signals from insulin and some growth factors (Veverka et al., 2008). The present data underscore that greater availability of Ile and Val when the ratio of Lys:Met is ideal increased phosphorylation of mTORC1, indicating these AA could further stimulate milk protein synthesis. As a whole, however, increasing Val was most important in terms of phosphorylation of mTORC1 and Akt, and upregulation of various AA transporters and casein genes.

It is noteworthy that, unlike Ile and Val, treatment with LT1.3 led to lower phosphorylation ratio of Akt and mTORC1, which could have resulted from feedback inhibition of the IRS1/Akt/mTOR pathway. It has been demonstrated that rapamycin, an inhibitor of mTORC1, could increase the mRNA abundance of IRS1 and promote the phosphorylation of Akt (O'Reilly et al., 2006). Because Akt activation is mainly induced by insulin and the same dosage of insulin was used for all treatments, the data suggest that Val (in particular) could regulate Akt phosphorylation status potentially through sensitizing the response of Akt to insulin. Although there is some evidence that insulin regulates the activity of Akt independent of AA (Appuhamy et al., 2011a), the response to Val was similar to previous work in bovine mammary epithelial cells (Burgos et al., 2010). Further studies will have to be performed to better understand the linkages between insulin and EAA.

The proteins 4EBP1 and S6K1 serve as parallel regulators of mRNA translation (Ruvinsky and Meyuhas, 2006). The 4EBP1 mediates the formation of eIF4F to promote the translation initiation by releasing the phosphorylated eIF4E (Proud, 2004; Avruch et al., 2009). The greater phosphorylation status of 4EBP1 in response to LT1.3 and LI1.29 suggested that increasing Thr and Ile supplementation might promote translation initiation. Our findings are consistent with previous research in mouse mammary cells (Liu et al., 2017).

In general, there is a positive association between phosphorylation status of mTORC1 and 4EBP1 as was detected with LI1.29. The opposite was observed with LT1.3. Based on data indicating that only rapamycin and Akt inhibitors used together can markedly decrease the phosphorylation of $4 \mathrm{EBP} 1$ (Mi et al., 2015), we speculate that a feedback mechanism exists in the mTORC1-4EBP1 signaling pathway. The exact mechanisms for these responses will need further research. Along with the greater mTORC1 phosphorylation, the tendency for greater 4EBP1 phosphorylation in response to LV1.12 underscored the potential for Val to affect milk protein synthesis partly through the mTORC1-4EBP1 signaling pathway. A similar response was reported in a study with mammary tissue slices and porcine trophectoderm cells (Kong et al., 2012; Appuhamy et al., 2014).

Phosphorylation of S6K1 also is associated with mTORC1 activity (Appuhamy et al., 2012). It has been demonstrated that active S6K1 could activate eIF4B and eIF3 and inactivate PDCD4 to promote translation initiation via phosphorylation (Xie and Proud, 2014). Therefore, the great trend to increase phosphorylation of S6K1 with LV1.12 and LL0.78 is further indication that increasing availability of Val and Leu could positively affect mRNA translation.

Both eEF2 and RPS6 are downstream targets of S6K1. When dephosphorylated, eEF2 promotes mRNA translation elongation (Proud, 2004). Previous studies demonstrated an inverse association between the phosphorylation status of eEF2 and mTORC1 in BMEC (Appuhamy et al., 2011a). Except for LI1.29, in the present study, no significant difference in eEF2 phosphorylation was observed in response to LT1.3, LV1.12, and LL0.78 despite the marked increase in phosphorylation with LV1.12. These responses suggested that other factors might play a role in the regulation of eEF2 phosphorylation in addition to EAA signaling, and particularly the supplementation of Val.

A previous study demonstrated that RPS6 could be activated by the mTORC1/S6K1 pathway and stimulate mRNA translation and overall protein synthesis (Jefferies et al., 1997). In the present study, the higher RPS6 phosphorylation status with LV1.12 and LL0.78 compared with IPAA was consistent with prior experiments in human HEK293 cells, rat L6 myoblasts and BMEC (Kimball et al., 1999; Tang et al., 2001; Appuhamy et al., 2012). Although Leu also significantly increased phosphorylation of RPS6, the fact that Val resulted in a 5-fold increase in phosphorylation of RPS6 along with marked increases in mTORC1 and Akt phosphorylation underscore the uniqueness of this EAA in the control of protein synthesis in mammary cells.

The eIF $2 \alpha$ plays a critical role for the initiation of mRNA translation by mediating the recruitment of the Met-tRNA to the 40S ribosomal subunits (Appuhamy et al., 2012). Phosphorylated eIF2 $\alpha$ could decrease the binding efficiency of Met-tRNA to the 40S ribosomal subunits (Kimball, 1999). In a previous study, a jugular infusion of EAA reduced eIF2 $\alpha$ phosphorylation 
in mammary tissue of lactating cows (Toerien et al., 2010). In contrast, AA deprivation resulted in higher phosphorylation of eIF $2 \alpha$ in mouse liver and skeletal muscle (Anthony et al., 2004). Therefore, taking into account the upregulation of CSN2 and CSN1S1 along with increases in phosphorylation of Akt, mTORC1, and RPS6, the downregulation of eIF2 $\alpha$ phosphorylation with LV1.12 would have provided optimal conditions to stimulate protein synthesis beyond incubation with IPAA.

\section{Methylation}

A previous in vivo study demonstrated that CSN1S1 abundance could be regulated in part by the methylation status in response to environmental factors, milking frequency, and stage of lactation (Nguyen et al., 2014). The greater percentage of CSN1S1 methylation induced by LV1.12 along with the upregulation of CSN1S1 indicate that this EAA can alter methylation status without causing its downregulation or that the CpG sites evaluated might have less effect on the final transcription of CSN1S1. It also should be noted that our data pertain to $\mathrm{CpG}$ regions in the promoter rather than a distal upstream region as measured by Nguyen et al. (2014); thus, the data are not directly comparable between studies. In addition, because the MAC-T cell line does not secrete protein, the changes observed at the mRNA abundance level might not be directly extrapolated to an in vivo condition. However, given that LV1.12 caused changes at the mRNA, protein, and metabolite level indicating a positive effect on milk protein synthesis, it could be speculated that these responses are biologically relevant. Clearly, additional experiments are needed to clarify these results.

\section{CONCLUSIONS}

Our research provided more systematic evidence based on metabolomics that EAA ratios could affect protein synthesis in part by regulating intracellular metabolism. An increase in availability of Val relative to Lys (Lys:Val, 1.12:1) when Lys:Met is ideal could further stimulate milk protein synthesis by optimizing the profile of intracellular EAA, enhancing the activity of mTORC1, upregulating mRNA abundance of AA transporters, $\beta$-casein, and $\alpha_{S_{1}}$-casein and methylation of $\alpha_{S_{1}}$-casein. Future studies should be performed to verify these responses in vivo.

\section{ACKNOWLEDGMENTS}

Xianwen Dong is a recipient of a doctoral scholarship from China Scholarship Council (Beijing).

\section{REFERENCES}

Anthony, T. G., B. J. McDaniel, R. L. Byerley, B. C. McGrath, D. R. Cavener, M. A. McNurlan, and R. C. Wek. 2004. Preservation of liver protein synthesis during dietary leucine deprivation occurs at the expense of skeletal muscle mass in mice deleted for eIF2 kinase GCN2. J. Biol. Chem. 279:36553-36561.

Appuhamy, J. A., A. L. Bell, W. A. Nayananjalie, J. Escobar, and M. D. Hanigan. 2011a. Essential amino acids regulate both initiation and elongation of mRNA translation independent of insulin in MAC-T cells and bovine mammary tissue slices. J. Nutr. 141:1209-1215.

Appuhamy, J. A., J. R. Knapp, O. Becvar, J. Escobar, and M. D. Hanigan. 2011b. Effects of jugular-infused lysine, methionine, and branched-chain amino acids on milk protein synthesis in high-producing dairy cows. J. Dairy Sci. 94:1952-1960.

Appuhamy, J. A., N. A. Knoebel, W. A. Nayananjalie, J. Escobar, and M. D. Hanigan. 2012. Isoleucine and leucine independently regulate mTOR signaling and protein synthesis in MAC-T cells and bovine mammary tissue slices. J. Nutr. 142:484-491.

Appuhamy, J. A., W. A. Nayananjalie, E. M. England, D. E. Gerrard, R. M. Akers, and M. D. Hanigan. 2014. Effects of AMP-activated protein kinase (AMPK) signaling and essential amino acids on mammalian target of rapamycin (mTOR) signaling and protein synthesis rates in mammary cells. J. Dairy Sci. 97:419-429.

Arriola Apelo, S. I., L. M. Singer, X. Y. Lin, M. L. McGilliard, N. R. St-Pierre, and M. D. Hanigan. 2014. Isoleucine, leucine, methionine, and threonine effects on mammalian target of rapamycin signaling in mammary tissue. J. Dairy Sci. 97:1047-1056.

Avruch, J., X. Long, S. Ortiz-Vega, J. Rapley, A. Papageorgiou, and N. Dai. 2009. Amino acid regulation of TOR complex 1. Am. J. Physiol. Endocrinol. Metab. 296:E592-E602.

Bionaz, M., and J. J. Loor. 2008. Gene networks driving bovine milk fat synthesis during the lactation cycle. BMC Genomics 9:366.

Bionaz, M., and J. J. Loor. 2011. Gene networks driving bovine mammary protein synthesis during the lactation cycle. Bioinform. Biol. Insights 5:83.

Blarzino, C., R. Coccia, B. Pensa, C. Cini, and M. C. De. 1994. Selenomethionine as substrate for glutamine transaminase. Biochem. Mol. Biol. Int. 32:79-86.

Broer, S. 2014. The SLC38 family of sodium-amino acid co-transporters. Pflugers Arch. 466:155-172.

Brosnan, J. T., and M. E. Brosnan. 2013. Glutamate: A truly functional amino acid. Amino Acids 45:413-418.

Browne, G. J., and C. G. Proud. 2004. A novel mTOR-regulated phosphorylation site in elongation factor 2 kinase modulates the activity of the kinase and its binding to calmodulin. Mol. Cell. Biol. 24:2986-2997.

Burgos, S. A., M. Dai, and J. P. Cant. 2010. Nutrient availability and lactogenic hormones regulate mammary protein synthesis through the mammalian target of rapamycin signaling pathway. J. Dairy Sci. 93:153-161.

Chen, R., Y. Zou, D. Mao, D. Sun, G. Gao, J. Shi, X. Liu, C. Zhu, M. Yang, and W. Ye. 2014. The general amino acid control pathway regulates $\mathrm{mTOR}$ and autophagy during serum/glutamine starvation. J. Cell Biol. 206:173-182.

Clark, J. H., H. R. Spires, R. G. Derrig, and M. R. Bennink. 1977. Milk production, nitrogen utilization and glucose synthesis in lactating cows infused postruminally with sodium caseinate and glucose. J. Nutr. 107:631-644.

Davio, C., G. Cricco, G. Martin, C. Fitzsimons, R. Bergoc, and E. Rivera. 1994. Effect of histamine on growth and differentiation of the rat mammary gland. Agents Actions 41:C115-C117.

Davis, A. J., and R. E. Austic. 1997. Dietary protein and amino acid levels alter threonine dehydrogenase activity in hepatic mitochondria of Gallus domesticus. J. Nutr. 127:738-744.

Derrig, R., J. Clark, and C. Davis. 1974. Effect of abomasal infusion of sodium caseinate on milk yield, nitrogen utilization and amino acid nutrition of the dairy cow. J. Nutr. 104:151-159.

Doelman, J., J. J. Kim, M. Carson, J. A. Metcalf, and J. P. Cant. 2015. Branched-chain amino acid and lysine deficiencies exert 
different effects on mammary translational regulation. J. Dairy Sci.98:7846-7855.

Doerks, T., R. R. Copley, J. Schultz, C. P. Ponting, and P. Bork. 2002. Systematic identification of novel protein domain families associated with nuclear functions. Genome Res. 12:47-56.

Dong, X., Z. Zhou, B. Saremi, A. Helmbrecht, Z. Wang, and J. J. Loor. 2018. Varying the ratio of Lys:Met while maintaining the ratios of Thr:Phe, Lys:Thr, Lys:His, and Lys:Val alters mammary cellular metabolites, mammalian target of rapamycin signaling, and gene transcription. J. Dairy Sci. 101:1708-1718. https://doi.org/ $10.3168 /$ jds.2017-13351.

Floc'h, N. L., C. Obled, and B. Sève. 1996. In vivo threonine oxidation in growing pigs fed on diets with graded levels of threonine. Br. J. Nutr. 75:825

Fotiadis, D., Y. Kanai, and M. Palacin. 2013. The SLC3 and SLC7 families of amino acid transporters. Mol. Aspects Med. 34:139-158.

Gao, H. N., H. Hu, N. Zheng, and J. Q. Wang. 2015. Leucine and histidine independently regulate milk protein synthesis in bovine mammary epithelial cells via mTOR signaling pathway. J. Zhejiang Univ. Sci. B 16:560-572.

Giallongo, F., M. T. Harper, J. Oh, J. C. Lopes, H. Lapierre, R. A. Patton, C. Parys, I. Shinzato, and A. N. Hristov. 2016. Effects of rumen-protected methionine, lysine, and histidine on lactation performance of dairy cows. J. Dairy Sci. 99:4437-4452.

Grisolia, S., and P. P. Cohen. 1953. Catalytic role of glutamate derivatives in citrulline biosynthesis. J. Biol. Chem. 204:753-757.

Guinard, J., H. Rulquin, and R. Verite. 1994. Effect of graded levels of duodenal infusions of casein on mammary uptake in lactating cows. 1. Major nutrients. J. Dairy Sci. 77:2221-2231.

Han, C., H. Gu, J. Wang, W. Lu, Y. Mei, and M. Wu. 2013. Regulation of L-threonine dehydrogenase in somatic cell reprogramming. Stem Cells 31:953-965.

Haque, M. N., J. Guinard-Flament, P. Lamberton, C. Mustiere, and S. Lemosquet. 2015. Changes in mammary metabolism in response to the provision of an ideal amino acid profile at 2 levels of metabolizable protein supply in dairy cows: Consequences on efficiency. J. Dairy Sci. 98:3951-3968

Haque, M. N., H. Rulquin, A. Andrade, P. Faverdin, J. L. Peyraud, and S. Lemosquet. 2012. Milk protein synthesis in response to the provision of an "ideal" amino acid profile at 2 levels of metabolizable protein supply in dairy cows. 95:5876-5887. https://doi.org/ $10.3168 /$ jds.2011-5230

Haque, M. N., H. Rulquin, and S. Lemosquet. 2013. Milk protein responses in dairy cows to changes in postruminal supplies of arginine, isoleucine, and valine. J. Dairy Sci. 96:420-430. https://doi .org/10.3168/jds.2012-5610.

Heublein, S., S. Kazi, M. H. Ogmundsdottir, E. V. Attwood, S. Kala, C. A. Boyd, C. Wilson, and D. C. Goberdhan. 2010. Proton-assisted amino-acid transporters are conserved regulators of proliferation and amino-acid-dependent mTORC1 activation. Oncogene 29:4068-4079.

Hosseini, A., M. R. Tariq, F. Trindade da Rosa, J. Kesser, Z. Iqbal, O. Mora, H. Sauerwein, J. K. Drackley, E. Trevisi, and J. J. Loor. 2015. Insulin sensitivity in adipose and skeletal muscle tissue of dairy cows in response to dietary energy level and 2,4-thiazolidinedione (TZD). PLoS One 10:e0142633.

Huhtanen, P., and A. Hristov. 2009. A meta-analysis of the effects of dietary protein concentration and degradability on milk protein yield and milk N efficiency in dairy cows. J. Dairy Sci. 92:32223232 .

Inoki, K., Y. Li, T. Zhu, J. Wu, and K. L. Guan. 2002. TSC2 is phosphorylated and inhibited by Akt and suppresses mTOR signalling. Nat. Cell Biol. 4:648-657.

Issaq, H. J., and T. D. Veenstra. 2013. Proteomic and Metabolomic Approaches to Biomarker Discovery. Academic Press, Cambridge, MA.

Jefferies, H. B., S. Fumagalli, P. B. Dennis, C. Reinhard, R. B. Pearson, and G. Thomas. 1997. Rapamycin suppresses 5' TOP mRNA translation through inhibition of p70 s6k. EMBO J. 16:3693-3704.

Jewell, J. L., R. C. Russell, and K. L. Guan. 2013. Amino acid signalling upstream of mTOR. Nat. Rev. Mol. Cell Biol. 14:133-139.
Kadegowda, A., M. Bionaz, L. Piperova, R. Erdman, and J. Loor. 2009. Peroxisome proliferator-activated receptor- $\gamma$ activation and long-chain fatty acids alter lipogenic gene networks in bovine mammary epithelial cells to various extents. J. Dairy Sci. 92:4276-4289.

Karasov, W. H., D. H. Solberg, and J. M. Diamond. 1987. Dependence of intestinal amino acid uptake on dietary protein or amino acid levels. Am. J. Physiol. 252:G614-G625.

Kelly, A., and C. A. Stanley. 2001. Disorders of glutamate metabolism. Ment. Retard. Dev. Disabil. Res. Rev. 7:287-295.

Kim, C. H., J. J. Choung, and D. G. Chamberlain. 1999. Determination of the first-limiting amino acid for milk production in dairy cows consuming a diet of grass silage and a cereal-based supplement containing feather meal. J. Sci. Food Agric. 79:1703-1708.

Kimball, S. R. 1999. Eukaryotic initiation factor eIF2. Int. J. Biochem. Cell Biol. 31:25-29.

Kimball, S. R., and L. S. Jefferson. 2006. New functions for amino acids: effects on gene transcription and translation. Am. J. Clin. Nutr. 83:500S-507S.

Kimball, S. R., L. M. Shantz, R. L. Horetsky, and L. S. Jefferson. 1999. Leucine regulates translation of specific mRNAs in L6 myoblasts through mTOR-mediated changes in availability of eIF4E and phosphorylation of ribosomal protein S6. J. Biol. Chem. 274:11647-11652.

Kong, X., B. Tan, Y. Yin, H. Gao, X. Li, L. A. Jaeger, F. W. Bazer, and G. Wu. 2012. L-Arginine stimulates the mTOR signaling pathway and protein synthesis in porcine trophectoderm cells. J. Nutr. Biochem. 23:1178-1183.

Lapierre, H., G. Lobley, L. Doepel, G. Raggio, H. Rulquin, and S. Lemosquet. 2012. Triennial Lactation Symposium: Mammary metabolism of amino acids in dairy cows. J. Anim. Sci. 90:1708-1721.

Lee, C. W., I. J. Cho, Y. J. Lee, Y. S. Son, I. Kwak, Y. T. Ahn, S. C. Kim, and W. G. An. 2014. Effects of dietary levels of glycine, threonine and protein on threonine efficiency and threonine dehydrogenase activity in hepatic mitochondria of chicks. Asian-australas. J. Anim. Sci. 27:69-76

Levengood, J., D. Schaeffer, and A. Ulanov. 2015. Metabolite profiles of male and female Humboldt penguins. Veterinary Sciences $2: 349-362$.

Li, S. S., J. J. Loor, H. Y. Liu, L. Liu, A. Hosseini, W. S. Zhao, and J. X. Liu. 2017. Optimal ratios of essential amino acids stimulate beta-casein synthesis via activation of the mammalian target of rapamycin signaling pathway in MAC-T cells and bovine mammary tissue explants. J. Dairy Sci. 100:6676-6688.

Liu, G. M., M. D. Hanigan, X. Y. Lin, K. Zhao, F. G. Jiang, R. R. White, Y. Wang, Z. Y. Hu, and Z. H. Wang. 2017. Methionine, leucine, isoleucine, or threonine effects on mammary cell signaling and pup growth in lactating mice. J. Dairy Sci. 100:4038-4050.

Lobley, G. E., S. O. Hoskin, and C. J. Mcneil. 2001. Glutamine in animal science and production. J. Nutr. 131(Suppl):2525S.

Loor, J. J., M. Bionaz, and J. K. Drackley. 2013. Systems physiology in dairy cattle: Nutritional genomics and beyond. Annu. Rev. Anim. Biosci. 2013:365-392. https://doi.org/10.1146/annurev -animal-031412-103728.

Manjarin, R., B. J. Bequette, G. Wu, and N. L. Trottier. 2014. Linking our understanding of mammary gland metabolism to amino acid nutrition. Amino Acids 46:2447-2462.

Mi, W., Q. Ye, S. Liu, and Q.-B. She. 2015. AKT inhibition overcomes rapamycin resistance by enhancing the repressive function of PRAS40 on mTORC1/4E-BP1 axis. Oncotarget 6:13962.

Nan, X., D. Bu, X. Li, J. Wang, H. Wei, H. Hu, L. Zhou, and J. J. Loor. 2014. Ratio of lysine to methionine alters expression of genes involved in milk protein transcription and translation and mTOR phosphorylation in bovine mammary cells. Physiol. Genomics 46:268-275.

Napolitano, L., M. Scalise, M. Galluccio, L. Pochini, L. M. Albanese, and C. Indiveri. 2015. LAT1 is the transport competent unit of the LAT1/CD98 heterodimeric amino acid transporter. Int. J. Biochem. Cell Biol. 67:25-33.

Newsholme, P., J. Procopio, M. M. R. Lima, T. C. Pithon-Curi, and C. Rui. 2003. Glutamine and glutamate - their central role in cell metabolism and function. Cell Biochem. Funct. 21:1-9. 
Nguyen, M., M. Boutinaud, B. Petridou, A. Gabory, M. Pannetier, S. Chat, S. Bouet, L. Jouneau, F. Jaffrezic, D. Laloe, C. Klopp, N. Brun, C. Kress, H. Jammes, M. Charlier, and E. Devinoy. 2014. DNA methylation and transcription in a distal region upstream from the bovine AlphaS1 casein gene after once or twice daily milking. PLoS One 9:e111556.

Nicklin, P., P. Bergman, B. Zhang, E. Triantafellow, H. Wang, B. Nyfeler, H. Yang, M. Hild, C. Kung, and C. Wilson. 2009. Bidirectional transport of amino acids regulates mTOR and autophagy Cell 136:521-534.

NRC. 2001. Nutrient Requirements of Dairy Cattle. 7th rev. ed. Natl. Acad. Press, Washington, DC.

O'Reilly, K. E., F. Rojo, Q. B. She, D. Solit, G. B. Mills, D. Smith, H. Lane, F. Hofmann, D. J. Hicklin, D. L. Ludwig, J. Baselga, and N. Rosen. 2006. mTOR inhibition induces upstream receptor tyrosine kinase signaling and activates Akt. Cancer Res. 66:1500-1508.

Osorio, J. S., C. B. Jacometo, Z. Zhou, D. Luchini, F. C. Cardoso, and J. J. Loor. 2016. Hepatic global DNA and peroxisome proliferatoractivated receptor alpha promoter methylation are altered in peripartal dairy cows fed rumen-protected methionine. J. Dairy Sci. 99:234-244.

Palacin, M., and Y. Kanai. 2004. The ancillary proteins of HATs: SLC3 family of amino acid transporters. Pflugers Arch. 447:490-494.

Prizant, R. L., and I. Barash. 2008. Negative effects of the amino acids Lys, His, and Thr on S6K1 phosphorylation in mammary epithelial cells. J. Cell. Biochem. 105:1038-1047. https://doi.org/ $10.1002 / j c b .21904$.

Proud, C. G. 2004. mTOR-mediated regulation of translation factors by amino acids. Biochem. Biophys. Res. Commun. 313:429-436.

Rai, K. P., H. R. Pradhan, B. K. Sharma, and S. K. Rijal. 2014. Histamine in foods: Its safety and human health implications. Journal of Food Science and Technology Nepal 8:1-11.

Rebsamen, M., L. Pochini, T. Stasyk, M. E. de Araujo, M. Galluccio, R. K. Kandasamy, B. Snijder, A. Fauster, E. L. Rudashevskaya, M. Bruckner, S. Scorzoni, P. A. Filipek, K. V. Huber, J. W. Bigenzahn, L. X. Heinz, C. Kraft, K. L. Bennett, C. Indiveri, L. A. Huber, and G. Superti-Furga. 2015. SLC38A9 is a component of the lysosomal amino acid sensing machinery that controls mTORC1. Nature 519:477-481.

Ruvinsky, I., and O. Meyuhas. 2006. Ribosomal protein S6 phosphorylation: From protein synthesis to cell size. Trends Biochem. Sci. 31:342-348.

Sancak, Y., T. R. Peterson, Y. D. Shaul, R. A. Lindquist, C. C. Thoreen, L. Bar-Peled, and D. M. Sabatini. 2008. The Rag GTPases bind raptor and mediate amino acid signaling to mTORC1. Science 320:1496-1501.

Shimobayashi, M., and M. N. Hall. 2014. Making new contacts: the mTOR network in metabolism and signalling crosstalk. Nat. Rev. Mol. Cell Biol. 15:155-162.

Storey, J. D. 2002. A direct approach to false discovery rates. J. R. Stat. Soc. Series B Stat. Methodol. 64:479-498.

Tang, H., E. Hornstein, M. Stolovich, G. Levy, M. Livingstone, D. Templeton, J. Avruch, and O. Meyuhas. 2001. Amino acid-induced translation of TOP mRNAs is fully dependent on phosphatidylinositol 3-kinase-mediated signaling, is partially inhibited by rapamycin, and is independent of S6K1 and rpS6 phosphorylation. Mol. Cell. Biol. 21:8671-8683.

Tang, M., X. Zhang, N. Dan, A. O. Changjin, and M. Gao. 2014. Effects of glycine on proliferation and apoptosis of mammary epithelial cells of dairy cows. Chinese J. Anim. Nutr. 26:2162-2168.
Toerien, C. A., D. R. Trout, and J. P. Cant. 2010. Nutritional stimulation of milk protein yield of cows is associated with changes in phosphorylation of mammary eukaryotic initiation factor 2 and ribosomal s6 kinase 1. J. Nutr. 140:285-292.

Veverka, V., T. Crabbe, I. Bird, G. Lennie, F. W. Muskett, R. J. Taylor, and M. D. Carr. 2008. Structural characterization of the interaction of mTOR with phosphatidic acid and a novel class of inhibitor: compelling evidence for a central role of the FRB domain in small molecule-mediated regulation of mTOR. Oncogene $27: 585-595$.

Wang, C., H. Liu, Y. Wang, Z. Yang, J. Liu, Y. Wu, T. Yan, and H. Ye. 2010. Effects of dietary supplementation of methionine and lysine on milk production and nitrogen utilization in dairy cows. J. Dairy Sci. 93:3661-3670.

Wang, C., J. Wang, Z. Ju, R. Zhai, L. Zhou, Q. Li, J. Li, R. Li, J. Huang, and J. Zhong. 2012. Reconstruction of metabolic network in the bovine mammary gland tissue. Mol. Biol. Rep. 39:73117318 .

Wang, D., X. Wan, J. Peng, Q. Xiong, H. Niu, H. Li, J. Chai, and S. Jiang. 2017. The effects of reduced dietary protein level on amino acid transporters and mTOR signaling pathway in pigs. Biochem. Biophys. Res. Commun. 485:319-327.

Wang, M. Z., L. Y. Ding, C. Wang, L. M. Chen, J. J. Loor, and H. R. Wang. 2017. Short communication: Arginase inhibition reduces the synthesis of casein in bovine mammary epithelial cells. J. Dairy Sci. 100:4128-4133.

Wang, S., Z. Y. Tsun, R. L. Wolfson, K. Shen, G. A. Wyant, M. E Plovanich, E. D. Yuan, T. D. Jones, L. Chantranupong, W. Comb, T. Wang, L. Bar-Peled, R. Zoncu, C. Straub, C. Kim, J. Park, B. L. Sabatini, and D. M. Sabatini. 2015. Metabolism. Lysosomal amino acid transporter SLC38A9 signals arginine sufficiency to mTORC1. Science 347:188-194.

Wiklund, S., E. Johansson, L. Sjoestroem, E. J. Mellerowicz, U. Edlund, J. P. Shockcor, J. Gottfries, T. Moritz, and J. Trygg. 2008. Visualization of GC/TOF-MS-based metabolomics data for identification of biochemically interesting compounds using OPLS class models. Anal. Chem. 80:115-122.

Wohlt, J., J. Clark, R. Derrig, and C. Davis. 1977. Valine, leucine, and isoleucine metabolism by lactating bovine mammary tissue. J. Dairy Sci. 60:1875-1882.

Xia, J., and D. S. Wishart. 2011. Web-based inference of biological patterns, functions and pathways from metabolomic data using MetaboAnalyst. Nat. Protoc. 6:743-760.

Xie, J., and C. G. Proud. 2014. Signaling crosstalk between the mTOR complexes. Translation 2:e28174.

Yang, Q., K. Inoki, E. Kim, and K.-L. Guan. 2006. TSC1/TSC2 and Rheb have different effects on TORC1 and TORC2 activity. Proc. Natl. Acad. Sci. USA 103:6811-6816.

Zhang, S. 2017. Novel metabolic and physiological functions of branched chain amino acids: A review. J. Anim. Sci. Biotechnol. $8: 10$.

Zheng, L., W. Zhang, Y. Zhou, F. Li, H. Wei, and J. Peng. 2016. Recent advances in understanding amino acid sensing mechanisms that regulate mTORC1. Int. J. Mol. Sci. 17:E1636.

Zhou, M. M., Y. M. Wu, H. Y. Liu, and J. X. Liu. 2015. Effects of phenylalanine and threonine oligopeptides on milk protein synthesis in cultured bovine mammary epithelial cells. J. Anim. Physiol. Anim. Nutr. (Berl.) 99:215-220. 